\title{
STJECANJE PRAVA VLASNIŠTVA DOSJELOŠĆU NA NEKRETNINAMA U DRUŠTVENOM VLASNIŠTVU U SVJETLU NOVE PRAKSE EUROPSKOG SUDA ZA LJUDSKA PRAVA
}

Damir Kontrec, dipl. iur., sudac

Vrhovni sud Republike Hrvatske
UDK: 347.233:341.231.145(4)

Ur.: 23. siječnja 2017.

Pr.: 6. veljače 2017.

Pregledni znanstveni rad

\section{Sažetak}

Dosjelost kao institut građanskog prava poznat je još od rimskog prava $i$ predstavlja način stjecanja prava vlasništva (i nekih drugih stvarnih prava) na temelju zakona. Rad se bavi stjecanjem prava vlasništva na temelju dosjelosti na nekretninama koje su bile u društvenom vlasništvu. Iako je sudska praksa zauzela shvaćanje daje rok za dosjelost na nekretninama u društvenom vlasništvu mogao početi teći tek od 8. listopada 1991. godine, tri odluke Europskog suda za ljudska prava (Trgo protiv Hrvatske, Radomilja i drugi protiv Hrvatske i Jakeljić protiv Hrvatske) otvaraju mogućnost da se u vrijeme potrebno za dosjelost računa i razdoblje prije 8. listopada 1991. godine. U radu se ukazuje u kojim se slučajevima shvaćanjem Europskog suda za ljudska prava može primijeniti i kakav je učinak tih odluka na praksu redovnih sudova u Republici Hrvatskoj.

Ključne riječi: dosjelost, redovna i izvanredna dosjelost, nekretnina u društvenom vlasništvu, pretpostavke za stjecanje prava vlasništva dosjelošću.

\section{UVOD}

Europski sud za ljudska prava ${ }^{1}$ u lipnju 2016. godine donio je dvije nove odluke u postupcima protiv Republike Hrvatske, kojima je potvrdio svoja stajališta iznesena u predmetu Trgo protiv Hrvatske, a tiču se stjecanja prava vlasništva dosjelošću na nekretninama koje su bile u društvenom vlasništvu i računanju u rok dosjelosti i razdoblja prije stupanja na snagu Zakona o vlasništvu i drugim stvarnima pravima. ${ }^{2} \mathrm{U}$ ovom radu analiziraju se relevantne odluke ESLJP-a i njihov utjecaj na sudsku praksu u Republici Hrvatskoj koja se bavila pitanjem stjecanja prava vlasništva dosjelošću na nekretninama u društvenom vlasništvu.

2 Narodne novine, br. 91/96., 68/98., 137/99., 22/00., 73/00., 129/00., 114/01., 79/06., 141/06., 146/08., 38/09., 153/09., 143/12., 152/14., dalje ZVDSP. 
Radi boljeg razumijevanja cijelog problema uvodno se govori općenito o dosjelosti kao institutu stvarnoga prava u Republici Hrvatskoj, prikazuju se odredbe Općeg građanskog zakonika ${ }^{3}$, Zakona o osnovnim vlasničkopravnim odnosima ${ }^{4}$ i ZVDSP-a koje su govorile o stjecanju prava vlasništva (i drugim stvarnih prava) na nekretninama dosjelošću.

Posebno se analizira ima li potrebe eventualno promijeniti sudsku praksu u ovom području, a s obzirom na odluke ESLJP-a.

\section{OPĆENITO O INSTITUTU DOSJELOSTI}

Institut dosjelosti ili uzukapije (lat. usucapio) poznat je još iz rimskog prava i održao se sve do današnjih modernih stvarnopravnih uređenja.

Dosjelost je stjecanje prava vlasništva neke stvari neprekidnim samostalnim posjedovanjem te stvari kroz zakonom određeno vrijeme. Neposredan pravni učinak dosjelosti stjecanje je prava vlasništva one stvari koju se samostalno posjedovalo, kojim se dotadašnja faktična vlast na stvari pretvara u pravnu vlast na njoj - pravo vlasništva. Neminovni posredan učinak stjecanja putem dosjelosti jest da ona osoba koja je do tada bila vlasnik, gubi to svoje dotadašnje pravo vlasništva stvari koju je stekao dosjedatelj, a ujedno u pravilu prestaju i druga prava koju su teretila tu stvar. Isto tako dotadašnjem vlasniku ne pripada nikakav odštetni zahtjev, kondikcijski ili verzijski zahtjev protiv dosjedatelja. Pravni učinci dosjelosti nastupit će po samom pravu (ipso iure) čim se ispune sve pretpostavke stjecanja putem dosjelosti. ${ }^{5}$ Iz toga dalje slijedi da stjecatelj vlasništvo stječe bez upisa u zemljišnu knjigu, no ako se isti ne bi upisao u zemljišnu knjigu, postoji opasnost da bi stjecatelj to pravo mogao izgubiti u korist osobe koja bi u dobroj vjeri (bona fidae) nekretninu stekla postupajući s povjerenjem u potpunost $i$ istinitost zemljišnih knjiga.

Kod toga se za stjecanje prava vlasništva dosjelošću zahtijeva ispunjavanje određenih pretpostavki. To je prije svega da stjecatelj ima posjed određene kvalitete, ovisno o tomu radi li se o redovnoj ili izvanrednoj dosjelosti, da taj posjed traje zakonom određeno vrijeme, da stvar koja je predmet dosjedanja bude sposobna biti predmetom stjecanja u vlasništvo putem dosjelosti, kao i da je stjecatelj sposoban tu stvar steći u vlasništvo dosjelošću. ${ }^{6}$

Značenje učinaka instituta dosjelosti u građanskom pravu nalazi se u pretvaranju činjeničnog u pravno stanje, omogućavanjem legaliziranja onoga što u stvarnosti postoji dulje vrijeme, a ispunjava barem minimalne uvjete za priznavanje od pravnog poretka, a što može imati za posljedicu gubitak prava vlasništva ili drugih stvarnih

3 Pravna pravila Općeg građanskog zakonika (dalje OGZ) primjenjuju se u Republici Hrvatskoj na temelju Zakona o način primjene pravnih propisa donesenih prije 6. travnja 1941. godine (Narodne novine, br. 73/91.).

4 Narodne novine, br. 53/91., dalje ZOVO. Taj je propis bio savezni propis bivše SFRJ, objavljen u Službenom listu SFRJ, br. 6/80., 36/90.

5 Nikola Gavella, Tatjana Josipović, Igor Gliha, Vlado Belaj, Zlatan Stipković, Stvarno pravo, Svezak prvi, 2. izmijenjeno i dopunjeno izd., Narodne novine, Zagreb, j 2007., str. 556-557.

6 Isto kao pod 5., str. 557-566. 
prava na jednoj strani odnosno stjecanju tih prava na drugoj. ${ }^{7}$

Prije samog prikaza odluka ESLJP-a koje se odnose na stjecanje prava vlasništva dosjelošću na nekretninama u društvenom vlasništvo, kratko ćemo prikazati kako je institut dosjelosti bio reguliran u OGZ-u, ZOVO-u, te kako je danas propisan odredbama ZVDSP-a, kao i relevantnu sudsku praksu.

\section{ZAKONSKO UREĐENJE INSTITUTA DOSJELOSTI NA PODRUČJU HRVATSKE}

\subsection{Opći građanski zakonik}

Opći građanski zakonik iz 1811. godine stupio je na snagu na području današnje Republike Hrvatske 1. svibnja 1853. godine. Zakonom o nevažnosti pravnih propisa donesenih prije 6. travnja 1941. godine i za vrijeme neprijateljske okupacije ${ }^{8}$ OGZ-u je oduzeta snaga propisa, pa su se sve do donošenja ZOVO-a 1980. godine primjenjivala pravna pravila OGZ-a, između ostalog i glede stjecanja prava vlasništva dosjelošću. Kod toga su nam relevantne odredbe paragrafa 1468. i 1472. OGZ-a, koje se i danas primjenjuju s obzirom na odredbu čl. 388. st. 1. ZVDSP-a koja propisuje da se stjecanje, promjena, pravni učinci i prestanak stvarnih prava od stupanja na snagu ovoga Zakona prosuđuju prema njegovih odredbama, ako prijelaznim i završnim odredbama ili posebnim zakonom nije što drugo propisano. U st. 2. određeno je da stjecanje, promjena, pravni učinci i prestanak stvarnih prava do stupanja na snagu ZVDSP-a se prosuđuje prema pravnim pravilima koja su se primjenjivala u trenutku stjecanja, promjene i prestanka prava i njihovih pravnih učinaka.

Institut dosjelosti propisan je pravnim pravilima OGZ, u kojim je navedeno sljedeće:

Ako se zastarjelo pravo uslijed zakonitog posjeda prenosi u isto vrijeme na koga drugoga; zove se pravo dosjeđeno, a način taj stečenja zove se dosjelost (\$ 1452. OGZ).

U onim mjestima, gdje još nema nikakvih urednih javnih knjiga, i gdje se stečenje stvari nepokretnih ima dokazati po sudskim spisima i po inim ispravama, ili ako stvar nije uknjižena na ime onoga, koji je doista posjeduje, dosjelost se svršuje tek poslije 30 godina (\$ 1468. OGZ).

Proti fiskusu to jest, proti upraviteljima državnih dobara i državne imovine, ukoliko zastari ima mjesta (\$ 287, 289 i 1456-1457), također protiv upraviteljima dobara crkvenih, općinskih $i$ inih dopuštenih tijela, nije dovoljno opće i redno vrijeme dosjelosti. Glede posjeda stvari pokretnih i posjeda stvari nepokretnih, ili služnosti $i$ inih prava na pomenutim stvarima, izvršivanih, i na ime posjednika upisanih u javne knjige, posjed se ima produžiti kroz 6 godina. Prava pomenute vrste, koja na ime posjednikovo nisu upisana u javne knjige, i sva ima prava mogu se protiv fiskusa $i$ gore naznačenim povlaštenim osobama steći samo posjedom od 40 godina (\$ 1472 .

7 Jasna Brežanski, Dosjelost kao način stjecanja stvarnih prava, dostupno na www.vsrh.hr. Vlado Belaj, Dosjelost kao oblik stjecanja vlasništva, Informator br. 4680 od 13. siječnja 1999.

8 Službeni list FNRJ, br. 86/46. i 105/47. 
OGZ).

Iz navedenih pravnih pravila vidljivo je da je OGZ poznavao redovnu i izvanrednu dosjelost. Kod toga valja naglasiti da je prema Načelnom mišljenju opće sjednice Saveznog Vrhovnog suda br. 3/60 od 4. travnja 1960. godine za redovnu dosjelost potrebno 20 godina posjedovanja, a ne 30 kako je to bilo propisano $u$ izvornom tekstu OGZ-a.

Iz navedenog slijedi da se na stjecanje prava vlasništva za razdoblje od 1945. do 1. rujna 1980. godine (dan stupanja na snagu ZOVO-a) primjenjuju navedena pravna pravila OGZ-a.

U sudskoj praksi i danas nailazimo na odluke u kojima se tužiteljima priznaje da su stekli pravo vlasništva dosjelošću u skladu s pravnim pravilima OGZ-a.

U presudi Rev-1431/1999-2 od 1. ožujka 2001. godine navedeno je:

Sud drugoga stupnja prihvatio je utvrđenje suda prvoga stupnja da je tužitelj putem svojih pravnih prednika bio oduvijek, pri tome misleći i na razdoblje prije drugog svjetskog rata u posjedu sporne k.č.br. 623/3 oranica i pašnjak Gmajna od 6 rali i 640 čhv, upisana u zk. ul. br. 2 k.o. Slunj, da se radi o poljoprivrednom zemljištu, koje je temeljem odredbe čl. 3. st. 3. Zakona o poljoprivrednom zemljištu ("Narodne novine” br. 34/91) upisano u vlasništvo tuženika, budući da je ranije bilo upisano kao općenarodna imovina s pravom korištenja Općine Slunj.

$S$ obzirom na utvrđeno činjenično stanje, sudovi nižeg stupnja pravilno su zaključili da su prednici tužitelja kao dugogodišnji posjed utužene nekretnine kroz razdoblje dostatno za stjecanje prava vlasništva dosjelošću i prije 6. travnja 1941. godine stekli pravo vlasništva na istim nekretninama dosjelošću...

Sudovi nižeg stupnja pravilno su ocijenili sporni vlasničkopravni odnos kroz primjenu pravnih pravila bivšeg OGZ-a sukladno odredbi čl. 388. st. 2. Zakona o vlasništvu i drugim stvarnim pravima ("Narodne novine" br. 91/96), je se na stjecanje stvarnih prava primjenjuju ona pravna pravila koja su važila u vrijeme stjecanja prava vlasništva. ${ }^{9}$

Nadalje u odluci Rev-x-294/15-2 od 31. ožujka 2015. godine pobliže se navodi kakva se kvaliteta posjeda traži od dosjedatelja:

"U konkretnom slučaju za razješenje odnosa između stranaka ima se primjenjivati mjedavno pravo koje je bilo na snazi u vrijeme nastanka tih odnosa, dakle pravna pravila Općeg građanskog zakonika, koja se primjenjuju na temelju čl. 4. Zakona o nevažnosti pravnih propisa donesenih prije 6. travnja 1941. i za vrijeme neprijateljske okupacije ("Službeni list” FNRJ broj 86/1946).

Prema pravnom pravilu iz paragrafa 1460. bivšeg OGZ za stjecanje prava vlasništva na temelju dosjelosti zahtijevalo se zakonit, pošten i istinit posjed, s time da onaj tko dosjelost svog posjeda temelji na vremenu od 30 ili 40 godina nije dužan dokazivati način stjecanja. ${ }^{10}$

Županijski sud u Dubrovniku u odluci Gž-1022/15 od 11. studenoga 2015. godine

9 Vrhovni sud Republike Hrvatske, Rev-1431/1999-2 od 1. ožujka 2001., http://vsrhmeridio/ sudskapraksa/Odluka Tekst.asp? ...19.1.2017.

10 Vrhovni sud Republike Hrvatske, Rev-x-294/2015-2 od 31. ožujka 2015., http://vsrhmeridio/ sudskapraksa/Odluka Tekst.asp? ...19.1.2017. 
iznosi shvaćanje vezano za stjecanje prava korištenja dosjelošću na nekretninama u društvenom vlasništvu do donošenja Ustava iz 1974. godine. U odluci se navodi:

Sve do stupanja na snagu ZOVO-a dana 1. rujna 1980. godine za stjecanje, promjenu i prestanak stvarnih prava primjenjuju se pravna pravila Općeg građanskog zakonika (dalje OGZ) koji je bi na snazi na području današnje RH do 6. travnja 1941. godine, pod pretpostavkom da ona nisu suprotna Ustavu i zakonima FNRJ / SFRJ $i$ njezinih federalnih jedinica.

Prvostupanjski sud je pravilno utvrdio da je od utemeljenja društvenog vlasništva do donošenja Ustava SFRJ od 21. veljače 1974. godine i ZUR-a između društvenih pravnih osoba bilo moguće stjecanje prava korištenja na nekretninama dosjelošću.

Međutim, po pravnim pravilima OGZ-a vrijeme posjedovanja kao pretpostavka za stjecanje prava vlasništva dosjelošću na nekretninama u državnom vlasništvu bilo je 40 godina (\$ 1472.), koji je rok u konkretnom slučaju relevantan, a nije protekao u razdoblju od 1953. do 1974. godine, za koje je prvostupanjski sud utvrdio da je teklo dosjedanje.

Tužba u ovom predmetu podnesena je dana 16. listopada 1996. godine, pa od 8. listopada 1991. godine, kad je ponovno bilo moguće stjecanje prava vlasništva dosjelošću na stvarima koje su na taj dan bile u društvenom vlasništvu, također nije protekao ni rok od 10 godina kvalificiranog posjeda za stjecanje prava vlasništva dosjelošću propisan odredbom čl. 159. st. 2. ZV-a. ${ }^{11}$

O pitanju stjecanja prava vlasništva dosjelošću na nekretnini koja je na dan 8. listopada 1991. godine bila u društvenom vlasništvu izjasnio se i Ustavni sud Republike Hrvatske u odluci U-IIII-1480/14 od 25. svibnja 2016. godine:

U postupku je utvrđeno da je sporna nekretnina (ranije kč.br. 1328/3 upisana u zk. ul. br. 935 k.o. Kerestinec, sada kč. br. 4369, upisana prije u zk. ul. br. 1729 k.o. Rakitje, a potom u zk. ul. br. 3420 iste k.o.) u zk. ul. br. 935 k.o. Kerestinec prenesena iz knjige Plemićkih dobara kao vlasništvo Zavoda za kolonizaciju u Zagrebu, da bi 1948. postala općenarodna imovina, a potom vlasništvo Republike Hrvatske (čl. 3. Zakona o poljoprivrednom zemljištu - "Narodne novine" br. 34/91).

Nadalje je utvrđeno da je tužiteljica, što osobno, a što po svojim pravnim prednicima u posjedu sporne nekretnine još od 1918.

Tužiteljica je tvrdila da je nekretninu njezin djed dobio od države 1918. kao agrar pa je prvostupanjski sud zbrojivši posjed tužiteljice od 1981. pa do 6. travnja 1941. i od 8. listopada 1991. do podnošenja tužbe 22. srpnja 2010., utvrdio da je ista u posjedu nekretnine 41 godinu $i 9$ mjeseci i ocijenio da su se time ispunili uvjeti iz paragrafa 1472. Općeg građanskog zakonika (dalje: OGZ), koji se primjenjuje na temelju čl. 1. Zakona o načinu primjene pravnih propisa donesenih prije 6. travnja 1941. godine ("Narodne novine" br. 73/91) i čl. 159. st. 4. Zakona o vlasništvu $i$ drugim stvarnima pravima (dalje ZOV) za stjecanje prava vlasništva dosjelošću samostalnim posjedovanjem u vremenu od četrdeset godina.

Međutim, prvostupanjski sudje pogrešno postupio kadje "zbrajao" posjedovanje od 1918. pa do 6. travnja 1941. i od 8. listopada 1991. do podnošenja tužbe 22. srpnja

11 Županijski sud u Dubrovniku, Gž-1022/2015 od 11. studenoga 2015., http://ingbiro.com/ sudska/sadržaj.aspx? - 19.1.2017. 
2010.

Naime, nije sporno da je nekretnina na dan 8. listopada 1991. bila u društvenom vlasništvu.

Prema odredbi čl. 388. st. 4. ZOV-a u rok za stjecanje vlasništva dosjelošću nekretnine koja je na dan 8. listopada 1991. bila u društvenom vlasništvu, kao $i$ za stjecanje stvarnih prava na toj nekretnini dosjelošću, ne računa se i vrijeme posjedovanja proteklo prije toga dana.

Prema tome, moguće je ocjenjivati je li do 6. travnja 1941. isteklo vrijeme za stjecanje prava vlasništva dosjelošću odnosno jesu li se za to ispunili uvjeti nakon 8. listopada 1991.

Prema paragrafu 1472. OGZ-a pravo vlasništva dosjelošću nekretnine u državnom vlasništvu moglo se steći posjedovanjem kroz 40 godina.

Stoga posjedovanje od 1918. do 1941. tužiteljica nije mogla steći pravo vlasništva nekretnine dosjelošću budući je istu posjedovala 23 godine.

Od 8. listopada 1991. do podnošenja tužbe 22. srpnja 2010. tužiteljica je u posjedu nekretnine 19 godina.

No prema čl. 159. st. 4. ZOV-a za stjecanje prava vlasništva stvari u vlasništvu tužene potrebno je posjedovanje kroz 40 godina, pa ni na taj način nisu ispunjeni uvjeti za stjecanje prava vlasništva.

Osporena odluka donesena je sukladno mjerodavnom pravu Republike Hrvatske i sudskoj praksi, a pravno stajalište i jedinstvenu primjenu zakona u odnosu na konkretni pravni odnos između tuženika i podnositeljice drugostupanjski sud je valjano i na ustavnopravno prihvatljiv način obrazložio.

Stoga je ocjena Ustavnog suda da postupak koji je prethodio ustavnosudskom nije rezultirao povredom ustavnog prava propisanog čl. 29. st. 1. Ustava Republike Hrvatske." 12

Iz navedenog se može zaključiti da je u vrijeme primjene pravnih pravila OGZ-a bilo moguće steći vlasništvo dosjelošću na nekretninama koje su bile u državnom vlasništvu i to samo ako su se rokovi ispunili do 6. travnja 1941. Pravna pravila OGZ-a o stjecanju prava vlasništva dosjelošću primjenjivala su se na sve nekretnine koje su bile u privatnom vlasništvu i to sve do stupanja na snagu ZOVO-a.

\subsection{Zakon o osnovnim vlasničkopravnim odnosima i Zakon o preuzi- manju Zakona o osnovnim vlasničkopravnim odnosima iz 1991.}

ZOVO je stupio na snagu 1. rujna 1980. godine i u čl. 28. i 29. bila su određena pravila glede dosjelosti. Tako je u čl. 28. bilo propisano da savjesni i zakoniti posjednik pokretne stvari, na koju drugi ima pravo vlasništva, stječe pravo vlasništva na tu stvar dosjelošću protekom tri godine, a savjesni i zakoniti posjednik nepokretne stvari, stječe pravo vlasništva na tu stvar dosjelošću protekom deset godina. Savjesni posjednik pokretne stvari, na koju drugi ima pravo vlasništva, stječe pravo vlasništva na tu stvar dosjelošću protekom deset godina, a kod nekretnina se tražio protek roka od

12 Ustavni sud Republike Hrvatske, U-III-1,480/2014 od 25. svibnja 2016., http://ingbiro.com/ sudska/sadržaj.aspx? - 19.1.2017. 
dvadeset godina. Posebno je bilo propisano da nasljednik postaje savjestan posjednik od trenutka otvaranja nasljedstva i ako je ostavitelj bio nesavjestan posjednik, a nasljednik to nije znao niti je mogao znati, s time da vrijeme za dosjelost počinje teći od trenutka otvaranja nasljedstva.

U čl. 29. ZOVO-a bilo je propisano da se na stvarima u društvenom vlasništvu dosjelošću ne može steći pravo vlasništva.

Zakonom o preuzimanju ZOVO-a ${ }^{13}$, koji je stupio na snagu 8. listopada 1991. godine, u čl. 3. stavljena je izvan snage, između ostalih, i odredba čl. 29. ZOVO-a. To znači da je od 8. listopada 1991. godine bilo moguće stjecati pravo vlasništva dosjelošću i na stvarima (pokretnim i nepokretnim) koje su bile u društvenom vlasništvu. Navedeno je imalo dalekosežne posljedice na razvoj stvarnopravnih odnosa na području Republike Hrvatske. ${ }^{14}$

I u tom razdoblju sudska praksa je donijela niz zanimljivih pravnih shvaćanja. Navodimo neka od tih shvaćanja koja nam se čine bitnima za temu ovog rada.

"Stjecanje prava korištenja na nekretninama u društvenom vlasništvu između društvenih pravnih osoba dosjelošću bilo je moguće do donošenja Ustava SFRJ iz 1974. godine i Zakona o udruženom radu..$^{15}$

Zabrana prava stjecanja vlasništva na nekretninama u društvenom vlasništvu ne odnosi se na vlasništvo već stečeno dosjelošću do 6. travnja 1941. godine neovisno o tome što je zemljište kasnije upisano kao društveno. ${ }^{16}$

Nekretnina na kojoj postoji pravo vlasništva može dosjelošću prijeći u društveno vlasništvo. ${ }^{17}$

Kada sporna čestica do nacionalizacije iz 1958. nije bila u društvenom vlasništvu, već u privatnom vlasništvu, postoji mogućnost stjecanja prava vlasništva dosjelošću ako je tužitelj sam ili po svom predniku bio u kvalificiranom posjedu prijepora do 26.12.1958. kao dana stupanja na snagu Zakona o nacionalizaciji najamnih zgrada $i$ građevinskog zemljišta. ${ }^{18}$

U postupku pred nižestupanjskim sudovima je utvrđeno da je spornu nekretninu (tada upisanu u zk. ul. br. 662 k.o. L.) 1905. kupila Općina Lupoglav; da je 1947. kao vlasnik iste upisana Narodna Republika Hrvatska (pod upravom mjesnog narodnog odbora u L. u svrhu uređenja prosvjetnog doma i pošte), a da se od 1964. nekretnina vodi kao društveno vlasništvo, od 1988. kao društveno vlasnišstvo s pravom korištenja MZ L., a od 1995. upisana je kao vlasništvo Općine Brckovljani, a označena je kao kč.br. 1724 - zgrada, dom i dvorište u Selu površine od $6862 \mathrm{~m} 2$ i upisana je u zk.ul. br. 1172 k.o. L., a nakon parcelacije označena kao kč. 1724/1 i 1724/2 i upisana u isti zk.ul.; da je tužiteljica u posjedu dijela navedene nekretnine u površini od $1.583 \mathrm{~m} 2$

13 Narodne novine, br. 53/91.

14 Mladen Žuvela, Vlasničkopravni odnosi, Zakon o vlasništvu i drugim stvarnim pravima, Zakon o zemljišnim knjigama, Organizator, Zagreb, 2004., str. 595; isti autor, Stjecanje vlasništva na nekretninama dosjelošću - neki materijalnopravni i postupovni aspekti, Aktualnosti hrvatskog zakonodavstva i pravne prakse, Godišnjak 15, 2008., str. 37 i dalje.

15 Vrhovni sud Republike Hrvatske - Rev 45/90 od 6. prosinca 1990., www.iusinfo.hr ...19.1.2017.

16 Vrhovni sud Republike Hrvatske, Rev 253/90 od 21. ožujka 1990., www.iusinfo.hr ...19.1.2017.

17 Vrhovni sud SR Hrvatske, Gzz-51/83 od 24. siječnja 1984., www.iusinfo.hr ...19.1.2017.

18 Vrhovni sud SR Hrvatske, Gzz 33/83 od 18. svibnja 1983., www.iusinfo.hr ...19.1.2017. 
(zgrada, skladište i dvorište od $1.243 \mathrm{~m} 2$ i zgrada i dvorište od $340 \mathrm{~m} 2$ ), što po svojem pravnom predniku, a što samostalno, još od 1947., naznačeno u skici izmjere (str. 25 spisa) kao kč.br. 1724/3 i 1724/4.

Na temelju navedenog činjeničnog utvrđenja, a polazeći od toga da tužiteljica svoj tužbenizahtjev temelji na dvije pravne osnove (građenje i dosjelost), nižestupanjski sudovi zaključuju da ni po jednoj od navedenih osnova tužiteljica nije stekla pravo vlasništva.

Tužiteljica u reviziji ponavlja svoje tvrdnje o tome, kako je osnovan njezin zahtjev za utvrđenje prava vlasništva na predmetnoj nekretnini i obrazlaže svoje revizijske prigovore na način kako je obrazlagala tužbeni zahtjev tijekom postupka pred nižestupanjskim sudovima.

Međutim, nižestupanjski sudovi su po nalaženju ovog revizijskog suda pravilno primijenili materijalno pravo odbijanjem predmetnog zahtjeva tužiteljice.

Prema pravnom pravilu iz paragrafa. 418. bivšeg OGZ, koji su primjenjuje na temelju čl. 2. Zakona o načinu primjene pravnih propisa donesenih prije 6. travnja 1941. ("Narodne novine", broj 73/91), temeljna pretpostavka za stjecanje prava vlasništva građenjem na tuđem zemljištu jest izvršena gradnja objekta od svoje građe po nekoj osobi (pri čemu je nužno da je graditelj bio savjestan, tj. da je gradio uz znanje i suglasnost vlasnika). Budući da iz utvrđenja nižestupanjskih sudova proizlazi da tužiteljica nije dokazala da je upravo ona (odnosno njezin pravni sljednik) izvršila predmetnu gradnju, slijedi da je odbijanjem njenog tužbenog zahtjeva za utvrđenje prava vlasništva po osnovi građenja (a time i za izdavanje tabularne isprave) pravilno primijenjeno materijalno pravo.

Također, pravilno je ocijenjen neosnovanim i zahtjev tužiteljice za utvrđenje prava vlasništva temeljem dosjelosti.

Naime, u rok za stjecanje prava vlasništva dosjelošću na nekretninama koje su na dan 8. listopada 1991. bile u društvenom vlasništvu ne računa se vrijeme posjedovanja proteklo prije 8. listopada 1991., jer je do tog datuma odredbom čl. 29. Zakona o osnovnim vlasničkopravnim odnosima ("Narodne novine”, broj 93/91 dalje: ZOVO) bilo izričito zabranjeno stjecanje prava vlasništva dosjelošću na stvari u društvenom vlasništvu, a kako to pravilno obrazlažu nižestupanjski sudovi.

Isto propisuje $i$ izmijenjena odredba čl. 388. st. 4. sada važećeg Zakona o osnovnim vlasničkopravnim odnosima ("Narodne novine", broj 114/01 - dalje: ZVDSP), a prema kojoj se u rok za stjecanje prava vlasništva dosjelošću na nekretninama koje su na dan 8. listopada 1991. bile u društvenom vlasništvu, ne računa vrijeme posjedovanja protekom prije tog datuma.

Neosnovano tužiteljica u reviziji ukazuje da se u predmetnom slučaju radi o tzv. "stečenim pravima" $i$ to temeljem ranije važećih propisa, konkretno o stjecanju prava korištenja nekretnine u društvenom vlasništvu između društvenih pravni osoba dosjelošću (mišljenje proširene opće sjednice Saveznog Vrhovnog suda br. 3/60 od 4. travnja 1960.), a koje da se stečeno pravo korištenja temeljem prijelaznih odredbi ZVDSP transformiralo u njeno pravo vlasništva.

Naime, u postupku utvrđeno da tužiteljica (njen pravni prednik) nije bila savjesni (pošteni) posjednik sporne nekretnine, pa tužiteljica, dakle, vlasništvo sporne 
nekretnine nije mogla steći temeljem dosjelosti, jer joj za taj osnov stjecanja nedostaje savjesnost (čl. 28. i dr. ranijeg ZOVO, odnosno pravno pravilo iz paragrafa 1463. bivšeg OGZ) budući da je prema utvrđenju nižestupanjskih sudova tužiteljica znala odnosno mogla znati da je tuženica odnosno ranije njen pravni prednik isključivi vlasnik spornog objekta. Stoga nije odlučno što je tužiteljica (odnosno njezin pravni prednik) te nekretnine držala u posjedu od 1947.

Slijedom rečenog, pravilan je zaključak nižestupanjski sudova da tužiteljica nije stekla vlasnišstvo sporne nekretnine niti po jednoj od navedenih pravnih osnova. ${ }^{19}$

Kako je već rečeno citiranim Zakonom o preuzimanju ZOVO-a iz 1991. godine omogućeno je stjecanje prava vlasništva dosjelošću i na stvarima u društvenom vlasništvu, što je sve skupa imalo dalekosežne posljedice u praksi. ${ }^{20}$

Takva je odluka zakonodavca izazvala određena pitanja i dileme u praksi. Primjerice uračunava li se u vrijeme potrebno za dosjelost na nekretninama u društvenom vlasništvu vrijeme posjedovanja prije 8 . listopada 1991. U tom smislu Vrhovni sud Republike Hrvatske već je u odluci Rev-3462/93 od 3. svibnja 1995. izrijekom odgovorio na navedenu dvojbu na način da se vrijeme prije 8 . listopada 1991. godine ne računa u tijek dosjelosti, već da dosjelost u tom slučaju počinje teći tek od 8. listopada 1991. godine. ${ }^{21}$ Razloga za takvo shvaćanje nalazimo u činjenici da je do 8. listopada 1991. godine prema čl. 29. ZOVO-a izrijekom bilo zabranjeno stjecanje prava vlasništva dosjelošću na nekretninama u društvenom vlasništvu. S druge strane, to je značilo da su sve nekretnine koje su do tada bile u društvenom vlasništvu, bez obzira na njihov status u prijelaznom razdoblju, glede dosjelosti došle pod opći režim.

\subsection{Zakon o vlasništvu i drugim stvarnim pravima}

Nakon toga donosi se ZVDSP, koji stupa na snagu 1. siječnja 1997. godine, a koji institut dosjelosti regulira na sljedeći način.

Stjecanje prava vlasništva dosjelošću spada u stjecanje prava vlasništva na temelju zakona, što predstavlja jedan od pravnih temelja stjecanja prava vlasništva propisanih u čl. 114. st. 1. ZVDSP-a. ${ }^{22}$

Prema odredbi čl. 159. ZVDSP-a propisane su pretpostavke za stjecanje prava vlasništva dosjelošću, propisani su različiti režimi za pokretne, nepokretne stvari, za stvari u vlasništvu Republike Hrvatske, jedinica lokalne i područne (regionalne)

19 Vrhovni sud Republike Hrvatske , Rev-x 27/09-2 od 13. svibnja 2014., www.iusinfo.hr ...19.1.2017.

20 Vidi opširnije o značaju i domašaju brisanja čl. 29. ZOVO-a u člancima - Jasna Brežanski, Još o stjecanju vlasništva dosjelošću na nekretninama u društvenom vlasništvu, Zbornik Pravnog Fakulteta Sveučilišta u Rijeci, vol. 30, br. 1, str. 601-628 (2009.); Petar Simonetti, Stjecanje prava vlasništva primjenom ustanove dosjelosti i uzurpacije na nekretninama koje su bile u društvenom vlasništvu, Zbornik Pravnog fakulteta Sveučilišta u Rijeci, vol. 29., br. 1(2008.), str. 27-70.

21 Izbor odluka Vrhovnog suda Republike Hrvatske, br. 1/2006, str. 6.-7.

22 Čl. 114. st. 1. ZVDSP glasi: Vlasništvo se može steći na temelju pravnog posla, odluke suda, odnosno druge nadležne vlasti, nasljeđivanjem i na temelju zakona. 
samouprave te stvari koje su u vlasništvu države ili drugih pravnih osoba koje ne traže za sebe dobitak nego služe za dobrotvorne ili druge općekorisne svrhe.

Tako se i nadalje razlikuje redovna i izvanredna dosjelosti. Kod toga samostalni posjednik pokretne stvari, čiji je posjed kvalificiran (zakonit, istinit i pošten ${ }^{23}$ ) stječe dosjelošću pravo vlasništva protekom tri godine, a kod nekretnine taj posjed mora trajati deset godina. Kod izvanredne dosjelosti, samostalni posjednik mora imati posjed koji je barem pošten. U tom slučaju vlasništvo pokretne stvari dosjelošću stječe se protekom roka od deset godina, a kod nepokretnih stvari dvadeset godina.

Posebna pravila vrijede za stvari koje su u vlasništvu Republike Hrvatske (centralne ili lokalnih jedinica), kao i u vlasništvu crkve i drugih pravnih osoba koje za sebe ne traže dobitak nego služe u dobrotvorne ili druge općekorisne svrhe. Kod tih stvari traži se da protekne dvostruko vrijeme od onoga koje se inače traži za redovnu, odnosno izvanrednu dosjelost.

U čl. 160. ZVDSP-a pobliže se propisuju pravila o tijeku vremena potrebnog za dosjelost. Tako je određeno da vrijeme potrebno za dosjelost počinje teći onoga dana kad je posjednik stupio u samostalni posjed stvari, a završava istekom posljednjeg dana vremena potrebnoga za dosjelost. U vrijeme potrebno za dosjelost uračunava se i vrijeme za koje su prednici sadašnjeg posjednika neprekidno posjedovali kao zakoniti, pošteni i istiniti samostalni posjednici, odnosno kao pošteni samostalni posjednici. Nasljednik pak postaje poštenim posjednikom od trenutka otvaranja nasljedstva i ako je njegov prednik (ostavitelj) bio nepošteni posjednik, no ne $\mathrm{i}$ ako je nasljednik to znao ili morao znati. Kad se poštenom posjedniku čiji posjed nije zakonit i istinit uračunava vrijeme kroz koje je njegov prednik stvar posjedovao zakonito, pošteno i istinito, tada će se pravo vlasništva steći istekom još onoliko vremena koliko je potrebno da pošteni posjednik stekne stvar dosjelošću. Kad se zakonitom, poštenom i istinitom posjedniku uračunava vrijeme kroz koje je njegov prednik stvar posjedovao pošteno, ali ne i zakonito i istinito, tada će se vlasništvo steći dosjelošću istekom još onoliko vremena koliko je potrebno da pošteni posjednik stvar stekne dosjelošću, osim ako stvar već nije stekao time što je njegov zakoniti, pošteni i istiniti posjed trajao onoliko vremena koliko je potrebno da zakoniti, istinit i pošteni posjednik stekne dosjelošću. Na prekid odnosno zastoj tijeka vremena dosjelosti na odgovarajući način se primjenjuju odredbe o prekidu, odnosno zastoju tijeka rokova za zastaru tražbina ${ }^{24}$.

Za temu ovog rada bitna je i odredba čl. 388. st. 4. ZVDSP-a. U izvornom tekstu ZVDSP-a iz 1996. godine čl. 388. st. 4. glasio je:

(4) U rok za stjecanje dosjelošću nekretnina koje su na dan 8. listopada 1991.

23 Čl. 18. ZVDSP glasi: (1) Posjed je zakonit ako posjednik ima valjani pravni temelj toga posjedovanja (pravo na posjed). (2) Posjed je istinit ako nije pribavljen ni silom, ni potajno ili prijevarom, ni zlouporabom povjerenja. Posjed koji je pribavljen silom, potajno ili prijevarom, ili zlouporabom povjerenja, postaje miran kad osobi od koje je tako pribavljen prestane njezino pravo da štiti svoj posjed koji joj je tako oduzet. (3) Posjed je pošten ako posjednik kad ga je stekao nije znao niti je s obzirom na okolnosti imao dovoljno razloga posumnjati da mu ne pripada pravo na posjed, ali poštenje prestaje čim posjednik sazna da mu pravo na taj posjed ne pripada.

24 Pravila o prekidu i zastoju zastare tražbina propisana su odredbama Zakona o obveznim odnosima (Narodne novine, br. 35/05., 41/08., 125/11., 78/15.) i to čl. 235. do 246. 
bile u društvenom vlasništvu, kao i za stjecanje stvarnih prava na tim nekretninama dosjelošću, računa se i vrijeme posjedovanja proteklo prije tog dana.

Upravo takva odredba ZVDSP-a iz 1996. godine izazvala je probleme i nedoumice u praksi, a čini nam se i kasnije dovela do odluka ESLJP-a koje ćemo prikazati u nastavku.

S obzirom na brisanje čl. 29. ZOVO-a Zakonom o preuzimanju ZOVO-a (stupio na snagu 8. listopada 1991.), te odredbu čl. 388. st. 4. ZVDSP-a prema tekstu iz 1996. godine, moglo bi se zaključiti da je na dan stupanja na snagu ZVDSP-a 1. siječnja 1997. bilo dopušteno steći pravo vlasništva na stvarima u društvenom vlasništvu na temelju dosjelosti i da se u vrijeme dosjelosti računalo i vrijeme koje je proteklo prije 8. listopada 1991. godine.

\subsection{Odluka Ustavnog suda Republike Hrvatske U-I-58/1997, U-I- 235/1997, U-I-237/1997, U-I-1053/1997, U-I-1054/1997 od 17. studenoga 1999.}

Već spomenuta odredba čl. 388. st. 4. ZVDSP-a bila je predmetom razmatranja Ustavnog suda Republike Hrvatske, te je isti ocijenio da se radi o neustavnoj odredbi i ukinuo je odlukom od 17. studenoga 1999. ${ }^{25}$ Vezano na citiranu odredbu u odluci Ustavnog suda između ostalog se navodi:

U članku 388. stavku 4. Zakona o vlasništvu, propisano je da se u rok za stjecanje dosjelošću nekretnina koje su na dan 8. listopada 1991. godine bile u društvenom vlasništvu, kao i za stjecanje stvarnih prava na tim nekretninama dosjelošću, računa $i$ vrijeme posjedovanja proteklo prije toga dana.

Predlagatelji pod 2) i 3) smatraju da osporavana odredba ide za tim da razni korisnici imovine koju su ju koristili bez ikavke osnove, sada tu imovinu steknu u vlasništvo, da ih se pogoduje na štetu vlasnika kojima je oteta u komunizmu, čime se pogoduju korisnici, a degradiraju vlasnici, zbog čega da ne postoji "osobito opravdan razlog" za retroaktivnost te odredbe. Ukazuju da vlasnici nisu dopuštenom samopomoći vraćali svoje vlasništvo i iz razloga jer nad njihovom otetom imovinom razni korisnici nisu mogli ništa steći. Također navode da nije moguće priznati retroaktivnu dosjelost, ako je ista bila do danas zabranjena.

Smatraju da je osporenom odredbom povrijeđen članak 3., članak 48. stavak 1. i članak 90. stavak 2. Ustava.

Predlažu pokrenuti postupak za ocjenu ustavnosti odredbe članka 388. stavka 4. Zakona o vlasništvu, i tu odredbu ukinuti.

Prijedlog je osnovan.

Osporena odredba jednom faktičnom stanju daje jednu uobičajenu kvalitetu i za ono vrijeme, kada je ta kvaliteta bila zakonom izrijekom isključena.

Naime, u članku 29. Zakona o osnovnim vlasničkopravnim odnosima bilo je propisano da se na stvari u društvenom vlasništvu pravo vlasništva ne može steći dosjelošću. Ta je odredba stavljena izvan snage člankom 3. Zakona o preuzimanju Zakona o osnovnim vlasničkopravnim odnosima ("Narodne novine" broj 53/91), pa

25 Narodne novine, br. 137/99. 
su sve nekretnine koje su do donošenja Ustava bile društveno vlasništvo, bez obzira na njihov status u prijelaznom periodu i glede dosjelosti došle pod opći režim.

$S$ obzirom da na to da stavljanje izvan snage u konkretnom slučaju, prema stajalištu Suda, znači samo ukidanje (ex nunc), a ne i poništavanje (ex tunc), valja zaključiti da se vrijeme posjedovanja stvari u društvenom vlasništvu do 8. listopada 1991. (dan stupanja na snagu Zakona o preuzimanju Zakona o osnovnim vlasničkopravnim odnosima) ne može računati u dosjelost, dakle dosjelost se treba računati tek od 8. listopada 1991.

Naime, posjednici stvari za koje je stjecanje dosjelošću bilo izrijekom zakonom isključeno, znali suda stvar nije sposobna za dosjedanje, a znali su to i ovlaštenici prava (upravljanja, raspolaganja, korištenja) na istoj stvari, pa nisu protiv opasnosti gubitka stvari zbog dosjedanja posjednika, niti morali koristiti odgovarajuća pravna sredstva. Stoga bi se u primjeni osporene odredbe moglo dogoditi da netko tko je imao neko imovinsko pravo, to pravo izgubi, što Ustav dopušta samo iznimno i uz naknadu.

Osim toga, osporena odredba omogućuje stjecanje vlasništva određenih stvari dosjelošću već i prije no što su rokovi dosjedanja za te stvari i počeli teći, i to upravo kad se za mnoge više stvari u društvenom vlasništvu, rokovi dosjelosti produžuju (stvari u vlasništvu Republike Hrvatske, županija i jedinica lokalne samouprave $i$ jedinica lokalne samouprave i uprave is njima izjednačenih pravnih osoba, kao $i$ stvari u vlasništvu crkve ili drugih pravnih osoba koje ne traže za sebe dobitak nego služe za dobrotvorne ili druge općekorisne svrhe - članak 159. stavak 4. Zakona o vlasništvu.

Zbog navedenog, Sud ocjenjuje da osporena odredba u materijalnom smislu nije u suglasnosti s najvišim vrednotama jednakosti, nepovredivosti vlasništva i vladavine prava iz članka 3. Ustava, i jamstva prava vlasništva iz članka 48. stavka 1. Ustava.

Nadalje, Sud zaključuje da osporena odredba ima povratno djelovanje, zbog čega ocjenjuje da ona nije u suglasju ni sodredbom članka 90. stavka 2. Ustava.

Vrlo brzo nakon te odluke Ustavnog suda donesen je Zakon o izmjenama $\mathrm{i}$ dopunama ZVDSP-a ${ }^{26}$ (stupio na snagu 20. prosinca 2001.), kojim je, između ostalog izmijenjena odredba čl. 388. st. 4. ZVDSP-a na način da novi tekst navedena stavka glasi:

U rok za stjecanje dosjelošću nekretnine koje su na dan 8. listopada 1991. bile u društvenom vlasništvu, kao i za stjecanje stvarnih prava na tim nekretninama dosjelošću, ne računa se i vrijeme posjedovanja proteklo prije toga dana.

Time smo se vratili na shvaćanja koja su i ranije pretezala u pravnoj teoriji i sudskoj praksi da se u rok za stjecanje prava vlasništva na temelju dosjelosti na nekretninama u društvenom vlasništvu ne može računati razdoblje posjedovanja prije 8. listopada 1991. godine.

26 Narodne novine, br. 114/01. 


\section{PRESUDE EUROPSKOG SUDA ZA LJUDSKA PRAVA}

Kao što je već navedeno u uvodu tri presude ESLJP-a dovode u pitanje aktualnu sudsku praksu u Republici Hrvatskoj, a glede stjecanja prava vlasništva na nekretninama koje su bile u društvenom vlasništvu. Radi boljeg razumijevanja $u$ nastavku ćemo iznijeti relevantne činjenice u svakom od tih predmeta, kao i shvaćanje ESLJP-a.

\section{Trgo protiv Hrvatske (Zahtjev br. 35298/04) od 11. lipnja 2009. ${ }^{27}$}

Tužitelj je 1997. podnio tužbu u parničnom postupku protiv općine Podgora i Republike Hrvatske tražeći da se utvrdi da je vlasnik određenih nekretnina, kao i upis svog prava vlasništva u zemljišnim knjigama. U činjeničnim navodima tužitelj je tvrdio da su sporne nekretnine bile u vlasništvu njegova pokojnog ujaka, kojem su ranije vlasti te nekretnine konfiscirale 1949. godine. Pokojna majka tužitelj (podnositelja zahtjeva pred ESLJP) bila je u posjedu spornih nekretnina od 1953. godine, a nakon njezine smrti u njihovu posjedu bio je podnositelj zahtjeva (od 16 . veljače 1992.).

Prvostupanjski sud prihvatio je zahtjev tužitelja u cijelosti i naložio upis prava vlasništva tužitelja u zemljišnim knjigama. Kod toga je prvostupanjski sud prihvatio da se tužitelju u vrijeme dosjedanja uzme u obzir i vrijeme od 1953. do 8. listopada 1991., pa kako je tužitelj, zajedno sa svojim prednicima bio u posjedu tih nekretnina 40 godina, ispunili su se uvjeti za stjecanje prava vlasništva dosjelošću.

Drugostupanjski sud je prihvatio žalbu tuženika, ukinuo pobijanu prvostupanjsku presudu i odbio zahtjev tužitelja. Kod toga je drugostupanjski sud zauzeo shvaćanje da se u rok dosjelosti ne može računati vrijeme proteklo prije 8. listopada 1991. godine, što znači da je primijenjena novelirana odredba čl. 388. st. 4. ZVDSP-a (izmjena iz 2001. godine).

Tužitelj je protiv takve odluke drugostupanjskog suda podnio ustavnu tužbu Ustavnom sudu Republike Hrvatske, koji ju je odbio, smatrajući da je drugostupanjska presuda donesena primjenom mjerodavna materijalnog prava, da su pravna stajališta drugostupanjskog suda valjano obrazložena te da tužitelju nije povrijeđeno ustavno jamstvo prava vlasništva i prava nasljeđivanja.

Treba dodati da je tužitelj tražio ponavljanje kaznenog postupka u kojem je došlo do konfiskacije spornih nekretnina, ali je taj zahtjev tužitelja odbačen zbog nedostatka aktivne legitimacije.

Tužitelj je u isto vrijeme pokrenuo i postupak povrata predmetnih nekretnina prema pravilima o denacionalizaciji.

Radomilja i drugi protiv Hrvatske (zahtjev br. 37685/10) od 28. lipnja 2016. ${ }^{28}$

Više tužitelja podnijeli su tužbu protiv Grada Splita pred Općinskim sudom u Splitu 19. travnja 2002. godine tražeći da im se prizna vlasništvo nad pet zemljišnih čestica, kao i upis njihova prava vlasništva u zemljišne knjige. Tvrdnja je tužitelja u tom predmetu bila, da iako su predmetne nekretnine bila uknjižene u zemljišnoj knjizi

27 Trgo protiv Hrvatske, https://uredzastupnika.gov.hr/UserImages//arhiva//TRGO,.pdf ...19.1.2017.

28 Radomilja i drugi protiv Hrvatske, https://uredzastupnika.gov.hr/sudska-praksa/clanak-1protokol-br-1-zastita-vlasnistva/150/doc/1289 ... 19.1.2017. 
na ime Općine Stobreč, prednika Grada Splita, da su bile u njihovu posjedu preko 70 godina.

Prvostupanjski sud prihvatio je osnovanim tužbeni zahtjev tužitelja i donio presudu da su tužitelji i njihovi prednici bili u neprekinutom bona fide posjedu barem od 1912. godine, te da je zakonski rok za stjecanje vlasništva dosjelošću istekao nakon proteka dvadeset godina, točnije 1932. godine.

Drugostupanjski sud odlučujući o žalbi tuženika preinačio je prvostupanjsku presudu i odbio tužbeni zahtjev tužitelja. Naime, drugostupanjski sud je smatrao da je prvostupanjski sud pravilno utvrdio činjenično stanje, ali je pogrešno primijenio materijalno pravo, budući da se sporna nekretnina nalazila u državnom vlasništvu (upisani vlasnik Općina Stobreč), pa kako su tužitelji u posjedu spornih nekretnina od 1912. godine, to do 1941. godine nije istekao rok od četrdeset godina, koliko je potrebno kada se radi o nekretnina u vlasništvu države.

I u ovom slučaju tužitelji su podnijeli ustavnu tužbu Ustavnom sudu, koji ju je odbio kao neosnovanu.

Jakeljić protiv Hrvatske (zahtjev 22768/12) od 28. lipnja 2016. ${ }^{29}$

Podnositelji zahtjeva kupili su tri zemljišne čestice od različitih vlasnika i to 25 . svibnja 1993., 21. veljače 1996. i 20. srpnja 1999. godine, s time da su u zemljišnim knjigama sve te čestice bile upisane kao vlasništvo Općine Stobreč, pravnog prednika tuženika Grada Splita.

Tužitelji su 4. travnja 2002. podnijeli tužbu protiv Grada Splita radi utvrđenja da su vlasnici predmetnih nekretnina, te da se izvrši upis prava vlasništva na njihovo ime u zemljišnoj knjizi. U tužbi su tvrdili da su predmetne nekretnine bile u posjedu njihovih prednika više od stotinu godina, pa kako se i to vrijeme računa u vrijeme dosjelosti, to smatraju da su vlasnici predmetnih nekretnina.

I u ovom slučaju prvostupanjski je sud prihvatio tužbeni zahtjev tužitelja i sudio u njihovu korist. Prije svega utvrdio je da su predmetne nekretnine bile u društvenom vlasništvu 8. listopada 1991., te da temeljem mjerodavnog zakonodavstva nije bilo moguće steći vlasništvo nad nekretninama u društvenom vlasništvu dosjelošću prije tog datuma, osim ako su uvjeti za to bili ostvareni prije 6. travnja 1941. godine. Sudovi su utvrdili da su prednici tužitelja bili u posjedu predmetnih nekretnina četrdeset godina prije 6. travnja 1941. godine, zbog čega su postali vlasnici tih nekretnina, koje su kasnije kupili tužitelji.

Drugostupanjski sud prihvatio je žalbu tuženika i preinačio prvostupanjsku presudu tako da je odbio zahtjev tužitelja. Drugostupanjski sud je utvrdio da su prednici tužitelja bili u posjedu tih nekretnina od 1912. godine, pa do 6. travnja 1941. godine nije prošlo četrdeset godina. Nakon 8 . listopada 1991. godine vrijeme proteklo prije 6. travnja 1941. godine nije nastavilo teći, već je počelo teći iznova.

I u ovom je slučaju Ustavni sud Republike Hrvatske odbio ustavnu tužbu tužitelja smatrajući da nisu počinjene ustavne povrede na koje su tužitelji ukazivali u tužbi.

Ako se analiziraju činjenice u sva tri predmeta može se zaključiti da u sva tri

29 Jakeljić protiv Hrvatske, https://uredzastupnika.gov.hr/sudska-praksa/clanak-1-protokol-br-1zastita-vlasnistva/150/doc/1288... 19.1.2017. 
predmeta podnositelji zahtjeva (tužitelji u parničnim predmetima) tvrde da su zajedno sa svojim prednicima u posjedu dugi niz godina te da na tim nekretninama ne postoje nikakva prava trećih osoba. Isto tako u sva tri slučaja u zemljišnim knjigama je kao vlasnik upisana jedinica lokalne samouprave, općina ili grad, odnosno njezin prednik, odnosno Republika Hrvatska. U predmetu Trgo podnositelj je u posjedu spornih nekretnina od 1953. godine, dok su u predmetima Radomilja i Jakeljić tužitelji u posjedu spornih nekretnina od 1912. godine. Razlika postoji i glede vremena podnošenja tužbe u parničnom postupku, pa je tako tužitelj Trgo parnicu pokrenuo u vrijeme dok je na snazi bila ranija odredba čl. 388. st. 4. ZVDSP-a (iz 1996.), dok su u preostala dva predmeta tužitelji tužbeni podnijeli nakon što je Ustavni sud Republike Hrvatske tu odredbu utvrdio protuustavnom i ukinuo je, te nakon što je zakonodavac promijenio sadržaj odredbe čl. 388. st. 4. ZVDSP-a.

Stajalište ESLJP-a

ESLJP je donoseći odluke u sva tri predmeta proveo test razmjernosti, tražeći i dajući pritom odgovor na sljedeća pitanja:

1. Je li došlo do miješanja u mirno uživanje vlasništva?

2. Je li miješanje bilo "propisano zakonom"?

3. Je li miješanje bilo u "javnom interesu"?

4. Je li miješanje bilo razmjerno, odnosno koje okolnosti u konkretnim slučajevima prevladavaju, daje li se prednost pravima osoba koje su pretrpjele posljedice neustavnog zakona ili odredbe nad pravima osoba kojima je isti pogodovao, točnije je li postignuta tražena poštena ravnoteža između zahtjeva općeg interesa i zahtjeva zaštite temeljnih prava pojedinaca, te je li podnositelju zahtjeva nametnut nerazmjeran i prekomjerni teret?

U svim slučajevima utvrđeno je da je na strani podnositelja zahtjev dovoljno utemeljen da bi ga se moglo smatrati "imovinom" (vlasništvom) zaštićenim Protokolom br. 1. čl. 1. Odbijanje drugostupanjskog suda da prizna vlasništvo podnositelja zahtjeva predstavlja akt miješanja u njegova vlasnička prava koja su zaštićena citiranim Protokolom.

Nadalje je utvrđeno da su presude drugostupanjskog suda, nakon ukidanja odredbe čl. 388. st. 4. ZVDSP-a zakonite i u ustavnopravnom i u građanskopravnom smislu, to tim više što se presude temelje na noveliranoj odredbi čl. 388. st. 4. ZVDSP-a.

ESLJP dalje smatra da na odluku Ustavnog suda o ukidanju odredbe čl. 388. st. 4. ZVDSP-a treba gledati kao na ispravak nepoštenih učinaka čl. 388. st. 4. ZVDSP-a iz 1996. godine, te da je stoga ista u "javnom interesu".

Glede razmjernosti miješanja ESLJP-a u presudi Trgo protiv Hrvatske ističe:

63. U svezi s tim, Sud ponavlja da su u situacijama kao što je situacija u ovom predmetu koja uključuje temeljitu reformu političkog, pravnog i gospodarskog sustava države tijekom prijelaza iz socijalističkog režima u demokratsku državu, nacionalne vlasti suočene s izuzetno teškom zadaćom postizanja ravnoteže između prava različitih osoba koje taj proces pogađa. U takvim okolnostima, tuženoj bi državi trebalo dati široku slobodu procjene (vidi prethodno citirani Jahn and Others, stavci 91-92, i mutatis mutandis Broniowski v. Poland (GC) br. 31443/96, stavak 18., ECHR 2004V). 
64. Sud primjećuje da je tijekom socijalističkog režima u Hrvatskoj, tj. dulje od četrdeset godina, stjecanje vlasništva imovine u društvenom vlasništvu dosjelošću bilo izričito zakonom zabranjeno. Sud se slaže s mišljenjem Ustavnog suda da s obzirom na spomenutu zabranu osobe koje su uživale određena prava u odnosu na stvari u društvenom vlasništvu (vidi stavak 6. ove presude) u razdoblju socijalizma nisu imale potrebu ostvarivati ta prava s jednakom odlučnošću niti koristiti odgovarajuća pravna sredstva kako bi zaštitili ta prava u odnosu na posjednike koji mogu steći vlasništvo dosjelošću kao kada ta zabrana ne bi postojala. Stoga je zakonodavac donošenjem članka 388. (4.) Zakona o vlasništvu iz 1996. godine zapravo donio retroaktivni propis, budući da je prijašnjem ponašanju pridružio pravne posljedice kojem u mjerodavno vrijeme nisu mogle biti pridružene. Učinivši to, propustio je pružiti priliku osobama koje su uživale prava na stvarima u društvenom vlasništvu da prilagode svoje ponašanje.

65. U tom kontekstu domaća su tijela, nastojeći postići ravnotežu između suprotstavljenih interesa, zauzela stajalište da sama činjenica da su posjednici imovine u društvenom vlasništvu tijekom kratkog vremenskog razdoblja, kraćeg od tri godine (između 1. siječnja 1997. godine dana stupanja na snagu Zakona o vlasništvu iz 1996. godine i 17. studenog 1999., dana ukidanja članka 388. (4.) tog Zakona od strane Ustavnog suda) imali pravnu priliku postati vlasnicima te imovine temeljem dosjelosti, nije dovoljna da prevagne nad pravima $i$ interesima trećih osoba (vidi stavak 60. ove presude) na toj imovini. Bilo kakvo drugo mišljenje značilo bi dopustiti da članak 388. (4.) nastavi postojati i proizvoditi posljedice čak i nakon što je ukinut kao neustavan te da time djelotvorno spriječi te treće osobe od ostvarivanja njihovih zakonski priznatih prava na imovini u društvenom vlasništvu.

66. Okrećući se konkretnim okolnostima ovog predmeta, Sud primjećuje da su domaći sudovi utvrdili; (a) da je vlasnik predmetnog zemljišta bio pokojni ujak podnositelja zahtjeva, (b) da je isto bilo konfiscirano 1949. godine od socijalističkih vlasti i da je od tada kao vlasnik istog upisana država, (c) da je majka podnositelja zahtjeva bila u posjedu zemljišta od 1953. godine, kao što je to nastavio biti $i$ podnositelj zahtjeva nakon njezine smrti 16. veljače 1992. godine. Nema naznaka da je bilo tko, osim same države, stekao bilo kakva prava na tom zemljištu tijekom socijalizma ili da je bilo koja (treća) osoba (vidi stavak 60. ove presude), osim samog podnositelja zahtjeva (vidi stavak 25. ove presude) ikada zahtijevala bilo kakva prava u odnosu na to zemljište. Sud stoga smatra da zabrinutosti koje su potaknule Ustavni sud da ukine članak 388. (4.) Zakona o vlasništvu iz 1996. godine nisu prisutne u predmetu podnositelja zahtjeva. Ta je odredba ukinuta kako bi se zaštitila prava trećih osoba, dok u predmetu podnositelja zahtjeva nisu bila uključena bilo kakva prava treciih osoba.

67. U tim okolnostima, Sud smatra da podnositelj zahtjeva koji se razumno oslonio na zakonodavstvo koje je kasnije ukinuto kao neustavno ne bi trebao s obzirom na izostanak bilo kakve štete u odnosu na prava drugih osoba - snositi posljedice greške koju je počinila sama država, donijevši takav neustavan propis. Zapravo, kao posljedica njegovog ukidanja, vlasništvo imovine koje je podnositelj zahtjeva stekao dosjelošću na temelju odredbe koja je kasnije ukinuta kao neustavna, 
vraćeno je državi kojoj je time pogodovala njezina vlastita greška. U svezi s tim, Sud ponavlja da rizik bilo kakve greške koje su počinila državna tijela mora snositi država te da se greške ne smiju ispravljati na trošak dotičnog pojedinca, posebice kada ne postoji drugi suprotstavljeni privatni interes (vidi Gashi v. Croatia, br. 32457/05, stavak 40., 13. prosinca 2007. i Radchikov v Russia, br. 65582/01, stavak 50., 24. svibnja 2007.).

68. Stoga je došlo do povrede članka 1. Protokola 1.

Identično shvaćanje ponovljeno je u lipnju 2016. godine u predmetu Radomilja $i$ drugi protiv Hrvatske i Jakeljić protiv Hrvatske. Iz navedena se može zaključiti da se povreda države sastoji u tomu što je donijela neustavni propis (čl. 388. st. 4. ZVDSP iz 1996.), da nitko drugi na predmetnim nekretninama nema, niti je iskazivao bilo kakva prava osim podnositelja zahtjeva, te da pogreška države ne može padati na teret osoba koje su pouzdajući se u propise koje je država donijela stekle određena prava.

Pravedna naknada materijalne štete

U sva tri predmeta podnositelji su tražili pravednu novčanu naknadu materijalne štete. No, u sva tri slučaja takva novčana naknada im nije dosuđena, već je ocijenjeno da nacionalno zakonodavstvo omogućava podnositeljima potpunu naknadu. Naime, ESLJP smatra da podnositelji zahtjeva u skladu s odredbom čl. 428.a Zakona o parničnom postupku može podnijeti zahtjev za ponavljanje postupka u odnosu na koji je ESLJP utvrdio povredu Konvencije. Stoga smatra da je najprimjereniji način popravljanja posljedica povrede Konvencije ponavljanje postupka na koji se odnosi prigovor. Radi toga ESLJP nije podnositeljima dosudio novčani iznos nematerijalne štete..$^{30}$

\section{UTJECAJ PRESUDA EUROPSKOG SUDA ZA LJUDSKA PRAVA NA SUDSKU PRAKSU U REPUBLICI HRVATSKOJ}

U pravnoj teoriji razmatran je učinak presude Trgo protiv Hrvatske na sudsku praksu u svezi s dosjelošću. Tako Peček ističe da iz navedene presude proizlazi da osoba koja je u razdoblju između 1. siječnja 1997 do 17. studenoga 1999. pokrenula parnicu uz primjenu čl. 388. st. 4. ZVDSP-a iz 1996. radi stjecanja prava vlasništva na nekretnini na temelju dosjelosti, i ishodila sudsku presudu, to je vlasništvo stekla zakonito jer se ta presuda ne može naknadno izmijeniti samo jer je Ustavni sud tu zakonsku odredbu naknadno ukinuo. ${ }^{31}$

Isti autor navodi da su se na presudu Trgo protiv Hrvatske stranke pozivale u Odluci broj U-III-6337/2012 od 13. studenog 2013. U tom predmetu Ustavni sud je odlučivao u predmetu u kojem je podnositelj pravna osoba $\mathrm{s}$ javnim ovlastima. Ustavna tužba je odbijena jer je utvrđeno da je podnositelj utvrđen, u prvostupanjskom postupku, vlasnikom ne na temelju dosjelosti, već na temelju čl. 16. Zakona o

30 Vidi opširnije o pravednoj naknadi i postupku pred ESLJP-om u Jasna Omejec, Konvencija za zaštitu ljudski prava i temeljnih sloboda u praksi Europskog suda za ljudska prava, Novi informator, Zagreb, 2013.

31 Robert Peček, Utjecaj presude "Trgo protiv Hrvatske" na sudsku praksu u svezi s dosjelošću, Informator, br. 6242-6243 od 1. i 4. siječnja 2014. 
Hrvatskom autoklubu, zbog čega stajališta ESLJP-a nisu neposredna primjenjiva u tom slučaja.

Vezano na ranije navedeno, nakon novih odluka ESLJP-a iz 2016. godine, čini nam se da više nije bitno za primjenu stajališta iz presude Trgo protiv Hrvatske je li tužba podnesena u razdoblju od 1. siječnja 1997. do 17. studenoga 1999. Naime, u predmetima Radomilja i drugi i Jakeljić protiv Hrvatske tužbe su podnesene 2002. godine, dakle nakon što je Ustavni sud ocijenio neustavnom odredbu čl. 388. st. 4. ZVDSP-a, te nakon što je donesena nova odredba čl. 388. st. 4. ZVDSP-a koja je izrijekom propisala da se razdoblje prije 8 . listopada 1991. ne uračunava u vrijeme dosjelosti glede nekretnina koje su bile u društvenom vlasništvu.

ESLJP u obrazloženju odluka u predmetima Radomilja i Jakeljić izričito navodi da je vrijeme kada je podnositelj podnio tužbu nevažno za određivanje može li se njegov zahtjev za proglašavanjem vlasnikom nekretnine dosjelošću okvalificirati kao "imovina" zaštićena čl. 1. Protokola br. 1. uz Konvenciju. Ono što je za ESLJP bitno je li vlasništvo nad predmetnom imovinom preneseno podnositelju zahtjeva prema zakonu u vrijeme kada je čl. 388. st. 4. ZVDSP-a iz 1996. bio u obliku u kojem je izvorno sročen još uvijek bio na snazi. Drugim riječima ESLJP smatra da je bitno je li došlo do stjecanja prava vlasništva na temelju zakona - dosjelošću ili ne i to u vrijeme kada je izvorna odredba čl. 388. st. 4. ZVDSP-a bila na snazi. To bi dalje značilo da bi se i danas mogla podnijeti tužba radi stjecanja vlasništva dosjelošću, uz tvrdnju da je to vlasništvo stečeno u navedenom periodu, ako su ispunjene ostale pretpostavke za stjecanje prava vlasništva dosjelošću i ako nitko treći na istim nekretninama nema nikakvih prava, niti je to na bilo koji način iskazano.

Vrhovni sud Republike Hrvatske se u više odluka bavio učincima presude Trgo protiv Hrvatske. Tako je u predmetu Rev-x 51/13-2 od 23. srpnja 2014. odbačena revizija tužitelja kao nedopuštena u kojem se tužitelj pozivao na citiranu presudu. Revizijski sud je zaključio da razlozi važnosti nisu pravilno naznačeni, te da se presuda Trgo protiv Hrvatske i stajališta zauzeta u njoj ne mogu primijeniti na konkretan slučaj jer u istome postoji treća osoba, čija su se prava štitila Odlukom Ustavnog suda o ukidanju prvotna čl. 388. st. 4. ZVDSP-a.

I u odluci Rev 1810/12-2 od 9. listopada 2014. tužiteljica se pozvala na učinke presude Trgo protiv Hrvatske, ali je i u njemu revizijski sud ocijenio da se navedena presuda ne može primijeniti jer se radi o činjenično i pravno različitoj situaciji od situacije u citiranoj odluci ESLJP-a.

\section{ZAKLJUČNE NAPOMENE}

Sudska praksa u Republici Hrvatskoj mora pratiti, analizirati, tumačiti i primjenjivati praksu ESLJP-a, a to jer u slučaju povrede nekog od konvencijskih prava, koja su vrlo često i ustavna prava, nezadovoljna stranka ima pravo podnijeti zahtjev ESLJP-a. Ponekad je teško razumjeti razloge zbog kojih je ESLJP presudio na određeni način, pri čemu razlog za to nalazimo prije svega u načinu na koji su pravnici u Republici Hrvatskoj obrazovani, a to je da moraju primjenjivati zakonske odredbe. Europsko pravo otvara nove vidike, zahtijeva tumačenje određenih normi 
i prije svega stalno i detaljno proučavanje. Samo daljnjom edukacijom pravnika u Republici Hrvatskoj, razumijevanjem europskog prava i odluka europskih sudova, moći ćemo postići da u budućnosti bude manje usvojenih zahtjeva protiv Republike Hrvatske pred europskim sudovima, a to znači i manje plaćenih naknada zbog povreda konvencijskih prava.

\section{LITERATURA}

1. Vlado Belaj, Dosjelost kao oblik stjecanja vlasništva, Informator, br. 4680 od 13. siječnja 1999.

2. Jasna Brežanski, Dosjelost kao način stjecanja stvarnih prava, www.vsrh.hr 19.1.2017.

3. Jasna Brežanski, Još o stjecanju vlasništva dosjelošću na nekretninama u društvenom vlasništvu, Zbornik Pravnog fakulteta Sveučilišta u Rijeci. vol. 30, br. 1, 2009., str. 601628.

4. Nikola Gavella, Tatjana Josipović, Igor Gliha, Vlado Belaj, Zlatan Stipković, Stvarno pravo, Svezak prvi, 2. izmijenjeno izd., Narodne novine, Zagreb, 2007.

5. Jasna Omejec, Konvencija za zaštitu ljudskih prava i temeljnih sloboda u praksi Europskog suda za ljudska prava, Novi informator, Zagreb, 2013.

6. Robert Peček, Utjecaj presude "Trgo protiv Hrvatske" na sudsku praksu u svezi s dosjelošću, Informator, br. 6242-6243 od 1. i 4. siječnja 2014.

7. Petar Simonetti, Stjecanja prava vlasništva primjenom ustanove dosjelosti i uzurpacije na nekretninama koje su bile u društvenom vlasništvu, Zbornik Pravnog fakulteta Sveučilišta u Rijeci, Vol. 29., br. 1., 2008., str. 27-70.,

8. Mladen Žuvela, Stjecanje vlasništva na nekretninama dosjelošću - neki materijalno pravni i postupovni aspekti, Aktualnosti hrvatskog zakonodavstva i pravne prakse, Godišnjak 15, 2008., str. 37. i dalje.

9. Mladen Žuvela, Vlasničkopravni odnosi, Zakon o vlasništvu i drugim stvarnim pravima, Zakon o zemljišnim knjigama, Organizator, Zagreb, 2004., str. 595.

10. Zakon o načinu primjene pravnih propisa donesenih prije 6. travnja 1941. godine, Narodne novine, br. 73/91.

11. Zakon o nevažnosti pravnih propisa donesenih prije 6. travnja 1941. godine i za vrijeme neprijateljske okupacije, Službeni lis" FNRJ, br. 86/46., 105/47.),

12. Zakon o obveznim odnosima, Narodne novine, br. 35/05., 41/08., 125/11., 78/15.),

13. Zakon o osnovnim vlasničkopravnim odnosima, Narodne novine, br. 53/91.,

14. Zakon o vlasništvu i drugim stvarnim pravima, Narodne novine" br. 91/96., 68/98., 137/99., 22/00., 73/00., 129/00., 114/01., 79/06., 141/06., 146/08., 38/09., 153/09., 143/12., 152/14.). 
Summary

\section{ACQUISITION OF OWNERSHIP RIGHTS BY USUCAPTION OF REAL PROPERTY IN SOCIAL OWNERSHIP IN THE LIGHT OF THE NEW PRACTICE OF THE EUROPEAN COURT OF HUMAN RIGHTS}

The paper deals with the usucaption as a mode of acquiring right on property in social ownership. It points to three important decisions of the European Court of Human Rights againts Croatia that have a direct impact on the jurisprudence of the ordinary courts in Republic of Croatia regarding acquisition of property rights by usucaption of real property in social ownership.

Keywords: usucaption, ordinary and extra ordinary usucaption, real estate in social ownership, prerequisites for acquiring ownership by usucaption.

Zusammenfassung

\section{ERWERB VON EIGENTUMSRECHTEN DURCH ERSITZUNG VON IMMOBILIEN IN SOZIALEM EIGENTUM IM KONTEXT DER NEUEN PRAXIS DES EUROPÄISCHEN GERICHTSHOFS FÜR MENSCHENRECHTE}

Dieser Artikel befasst sich mit der Ersitzung von Immobilien als einer Art des Erwerbs des Eigentumsrecht im gesellschaftlichen Eigentum. Er weist auf drei wichtige Entscheidungen des Europäischen Gerichtshofs für Menschenrechte gegen die Republik Kroatien hin, die einen direkten Einfluss auf das Rechtsdenken der ordentlichen Gerichte in der Republik Kroatien in Bezug auf den Erwerb von Eigentumsrecht durch Ersitzung von Immobilien in sozialem Eigentum haben.

Schlüsselwörter: Ersitzung, gewöhnliche und außergewöhnliche Ersitzung, Immobilien im gesellschaftlichen Eigentum, Voraussetzungen für den Erwerb des Eigentums durch Ersitzung. 
Riassunto

\section{ACQUISTO PER USUCAPIONE DI BENI DI PROPRIETÀ SOCIALE ALLA LUCE DELLA NUOVA GIURISPRUDENZA DELLA CORTE EUROPEA DEI DIRITTI DELL'UOMO}

L'usucapione quale istituto di diritto privato è conosciuto sin dai tempi del diritto romano e rappresenta un modo d'acquisto del diritto di proprietà (e di alcuni altri diritti reali) su base legale. Il lavoro tratta dell'acquisto del diritto di proprietà per usucapione su immobili che furono di proprietà sociale. Benché la giurisprudenza abbia accolto l'orientamento in base al quale il termine per l'usucapione sui beni immobili di proprietà sociale potrebbe iniziare a decorrere appena dall' 8 ottobre del 1991, tre decisioni della Corte europea dei diritti dell'uomo (Trgo v. Croazia, Radomilja e altri v. Croazia e Jakeljić v. Croazia) aprono la possibilità che il tempo necessario ad usucapire possa computare anche il periodo precedente all' 8 ottobre 1991. Nel lavoro si evidenzia in quali casi l'interpretazione della Corte europea dei diritti dell'uomo possa trovare applicazione e quali effetti tali decisioni sortiscano sulla giurisprudenza delle corti ordinarie nella Repubblica di Croazia.

Parole chiave: usucapione, usucapione ordinaria e straordinaria, immobile di proprietà sociale, presupposti per l'acquisto della proprietà per usucapione. 
